\title{
State-owned Enterprise Information Architecture Construction Methods
}

\author{
Tong-Qiang JIANG ${ }^{1, a}$, Ting-Shuang YAN $^{2, b, *}$ \\ ${ }^{1,2}$ College of Computer and Information Engineering, Beijing Technology \& Business University, \\ China, 100048
}

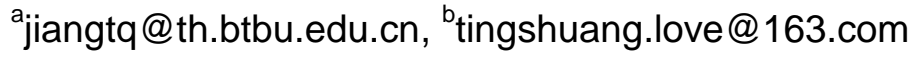

${ }^{*}$ Corresponding author

\begin{abstract}
Keywords: State-owned Enterprise, Business Process Architecture, Enterprise Information Architecture, Ontology.
\end{abstract}

\begin{abstract}
Enterprise Information Architecture (EIA) is a critical success factor for Business Process Re-engineering (BPR) and Information management. The knowledge of business information provides a vital leverage to the design of Enterprise Information Architecture. This paper proposes an approach for semantically deriving EIA of a state-owned enterprise from the ontological representations of a given Business Process Architecture (BPA) modeled using Riva method and modified using the BPAOnt Ontology by Yousef [1]. First this work extends the current BPAOnt Ontology before drawing information from it and then semantically represents the artifacts of the EIA based on both the BPAOnt and problem domain process ontologies.
\end{abstract}

\section{Introduction}

Currently state-owned enterprises have significantly improved the level of information. The awareness of information has gradually established. To some extent, the management level and the production efficiency of state-owned enterprises have been improved. But the state-owned enterprise information technology still has many problems, such as difficulties in data sharing, information between systems lack the standard system and so on, especially for the large state-owned enterprises which has multi-level sub-companies, these problems are more significant.

The key issue that the state-owned enterprise faced is to solve the "Information Islands", such as financial information and business information is not fused with the phenomenon. The reason is that most enterprises prefer to focus on technology rather than data when they build Enterprise Architecture. Only by establishing a data-level integration can solve this problem. If focus on data, we must build a suitable EIA. EIA is a core part of the Enterprise Architecture (EA), and it is closely linked with the Enterprise Business Architecture. So when we want to build EA, we should regard EIA as the core. How to build a state-owned EIA is the focus of this paper.

EA is also called the Overall Enterprise Information Architecture. It is a multi-angle business description and an overview of the enterprise. It reflects the business to people, process, technology, organization and arrangements, including the company's Business Architecture, Information or Data Architecture, Application Architecture and Technical Architecture, shown in Fig. 1.

EA describes an enterprise how to use the data now and in the future, including the classification and definition of information, information content and information flow and business modules combining data collection, storage, conversion, distribution and transmission. It provides the drawings, charts, plans, documents, designs and blueprints and templates to help people and efficient, innovative use of all types of related information [2]. EIA is the enterprise Business Process Management (BPM) and business process restructuring activities of the critical success factors. Researchers have realized that Information Architecture of business process reengineering is not only beneficial to the restructuring of the existing business process, but also support to define the generation of new business processes [3,4]. EIA is the foundation of Application Architecture and Technical Architecture. 


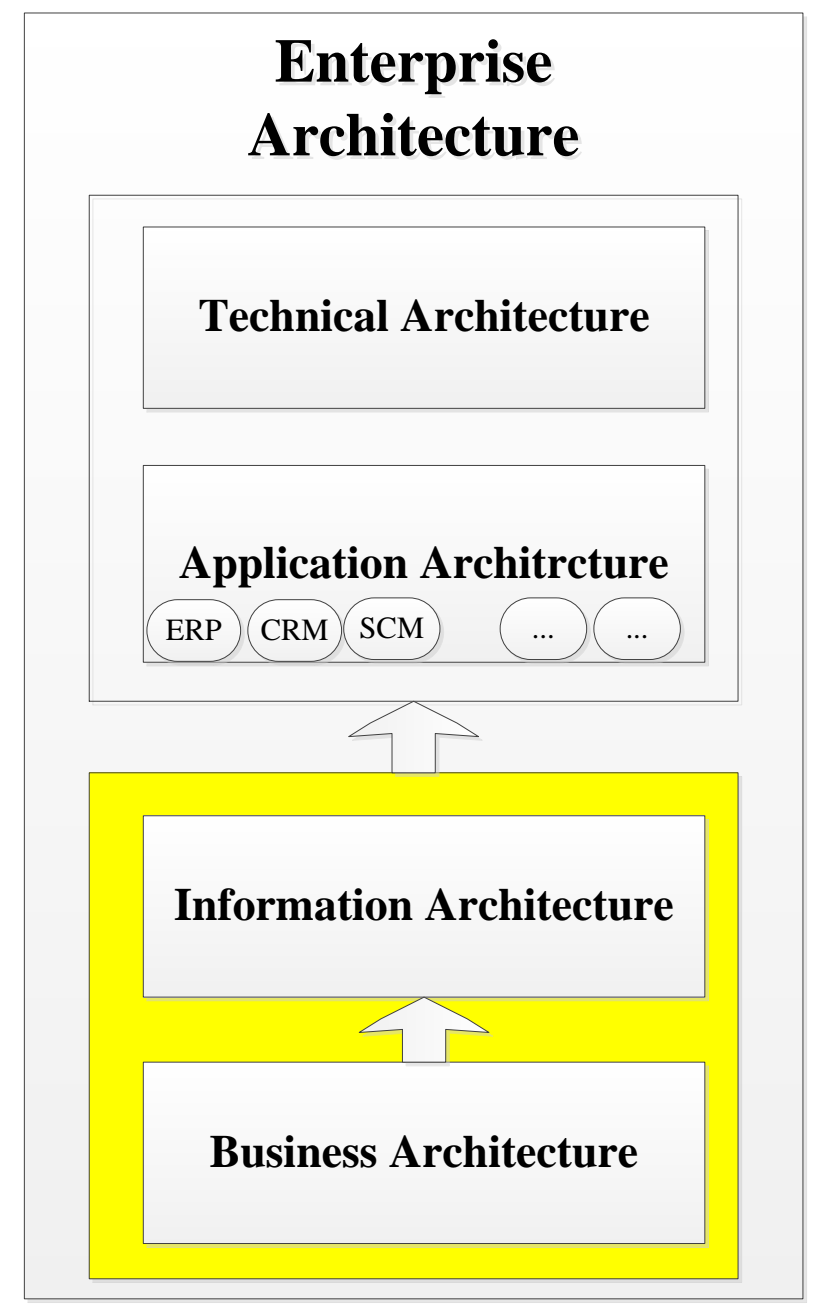

Fig.1 The Overview of Enterprise Architecture

\section{Related Works}

\section{The Current Situation of Enterprise Architecture Framework Method}

There are four popular Enterprise Architecture Framework methods: Zachman Framework, FEAF, DoDAF and TOGAF.

Zachman Framework. The Zachman framework is essentially a kind of classification method and the logical structure, which provides a definition of enterprise high formal and structured way. After several times of modification and the evolution, it formed the current view in 2008, consisting of a 6x6 classification matrix 36 cell, as shown in table 1. For the same complicated things, the Zachman Framework can describe the things from different angles, in different ways, for different purposes and in various forms, so it can provide the whole view of an enterprise [5].

FEAF. FEA is American Federal Enterprise Architecture which provides a general method in the federal government for the acquisition, use of IT technology. FEA is composed of five related reference models. Data Reference Model (DRM) is one of them. DRM can achieve data standardization through the background of data description, data sharing and other fields. Thereby it promotes inter-agency federal government be able to identify, use and share of data and information. Wang Jing Xuan in [6] and other State Information Center members study the FEAF in-depth research, and pointed FEA mainly engaged in the conduct of top-level design-driven, weakened the sector concept, and emphasized coordination and harmonization of business.

DoDAF. The Department of Defense Architecture Framework (DoDAF) provides a range of guidance and rules. It is based on a Department of Defense and its related companies. It's also a 
federal common approach among countries to develop, demonstrate and understand the system architecture. It provides the basis for the decision of the national defense system. It includes 8 view and 52 models. DoDAF enjoys wide application in military. Xie Zhihang in [7] pointed out that US army pays attention to the architecture design in Joint Operations in the requirements development process, and transforming the concept of Joint Operations for the weapon equipment development project.

Table 1 Zachman Framework

\begin{tabular}{|c|c|c|c|c|c|c|}
\hline & $\begin{array}{l}\text { DATA } \\
\text { What }\end{array}$ & $\begin{array}{c}\text { FUNCTI } \\
\text { ON } \\
\text { How } \\
\end{array}$ & $\begin{array}{c}\text { NETWO } \\
\text { RK } \\
\text { Where } \\
\end{array}$ & $\begin{array}{c}\text { PEOPLE } \\
\text { Who }\end{array}$ & $\begin{array}{l}\text { TIME } \\
\text { When }\end{array}$ & $\begin{array}{c}\text { MOTIV } \\
\text { ATION } \\
\text { Why } \\
\end{array}$ \\
\hline $\begin{array}{c}\text { Objective/Sc } \\
\text { ope } \\
\text { (contextual) } \\
\text { Role: } \\
\text { Planner } \\
\end{array}$ & $\begin{array}{l}\text { List of } \\
\text { things } \\
\text { important } \\
\text { in the } \\
\text { business }\end{array}$ & $\begin{array}{c}\text { List of } \\
\text { Business } \\
\text { Processes }\end{array}$ & $\begin{array}{c}\text { List of } \\
\text { Business } \\
\text { Locations }\end{array}$ & $\begin{array}{c}\text { List of } \\
\text { important } \\
\text { Organizat } \\
\text { ions }\end{array}$ & $\begin{array}{l}\text { List of } \\
\text { Events }\end{array}$ & $\begin{array}{c}\text { List of } \\
\text { Business } \\
\text { Goal \& } \\
\text { Strategies }\end{array}$ \\
\hline $\begin{array}{c}\text { Enterprise } \\
\text { Model } \\
\text { (contextual) } \\
\text { Role: Owner }\end{array}$ & $\begin{array}{c}\text { Conceptu } \\
\text { al } \\
\text { Data/Obje } \\
\text { ct Model }\end{array}$ & $\begin{array}{c}\text { Business } \\
\text { Process } \\
\text { Model }\end{array}$ & $\begin{array}{c}\text { Business } \\
\text { Logistics } \\
\text { System }\end{array}$ & $\begin{array}{l}\text { Work } \\
\text { Flow } \\
\text { Model }\end{array}$ & $\begin{array}{c}\text { Master } \\
\text { Schedule }\end{array}$ & $\begin{array}{c}\text { Business } \\
\text { Plan }\end{array}$ \\
\hline $\begin{array}{l}\text { System } \\
\text { Model } \\
\text { (logical) } \\
\text { Role: } \\
\text { Designer } \\
\end{array}$ & $\begin{array}{l}\text { Logistic } \\
\text { Data } \\
\text { Model }\end{array}$ & $\begin{array}{c}\text { System } \\
\text { Architect } \\
\text { ure Model }\end{array}$ & $\begin{array}{c}\text { Distribute } \\
\text { d System } \\
\text { Architect } \\
\text { ure }\end{array}$ & $\begin{array}{c}\text { Human } \\
\text { Interface } \\
\text { Architect } \\
\text { ure }\end{array}$ & $\begin{array}{l}\text { Processin } \\
\text { g } \\
\text { Structure }\end{array}$ & $\begin{array}{c}\text { Business } \\
\text { Rule } \\
\text { Model }\end{array}$ \\
\hline $\begin{array}{c}\text { Technology } \\
\text { Model } \\
\text { (physical) } \\
\text { Role: Builder }\end{array}$ & $\begin{array}{c}\text { Physical } \\
\text { Data/Clas } \\
\text { s Model }\end{array}$ & $\begin{array}{c}\text { Technolo } \\
\text { gy Design } \\
\text { Model }\end{array}$ & $\begin{array}{c}\text { Technolo } \\
\text { gy } \\
\text { Architect } \\
\text { ure } \\
\end{array}$ & $\begin{array}{l}\text { Presentati } \\
\text { on } \\
\text { Architect } \\
\text { ure }\end{array}$ & $\begin{array}{c}\text { Control } \\
\text { Architect } \\
\text { ure }\end{array}$ & $\begin{array}{c}\text { Rule } \\
\text { Design }\end{array}$ \\
\hline $\begin{array}{c}\text { Detailed } \\
\text { Representati } \\
\text { on } \\
\text { (out of } \\
\text { context) } \\
\text { Role: } \\
\text { Programmer } \\
\end{array}$ & $\begin{array}{c}\text { Data } \\
\text { Design }\end{array}$ & Program & $\begin{array}{c}\text { Network } \\
\text { Architect } \\
\text { ure }\end{array}$ & $\begin{array}{c}\text { Security } \\
\text { Architect } \\
\text { ure }\end{array}$ & $\begin{array}{c}\text { Timing } \\
\text { Definition }\end{array}$ & $\begin{array}{c}\text { Rule } \\
\text { Speculati } \\
\text { on }\end{array}$ \\
\hline $\begin{array}{l}\text { Functioning } \\
\text { Enterprise } \\
\text { Role: User }\end{array}$ & $\begin{array}{c}\text { Usable } \\
\text { Data }\end{array}$ & $\begin{array}{l}\text { Working } \\
\text { Function }\end{array}$ & $\begin{array}{c}\text { Usable } \\
\text { Network }\end{array}$ & $\begin{array}{c}\text { Functioni } \\
\text { ng } \\
\text { Organizat } \\
\text { ion } \\
\end{array}$ & $\begin{array}{l}\text { Implemen } \\
\text { ted } \\
\text { Schedule }\end{array}$ & $\begin{array}{l}\text { Working } \\
\text { Strategy }\end{array}$ \\
\hline
\end{tabular}

TOGAF. The Open Group Architecture Framework (TOGAF) includes four frameworks: Business Architecture, Data Architecture, Application Architecture and Technical Architecture (shown in fig. 2). In the process of development of the architecture, the Architecture Development Method ADM is the most critical [8]. Xu Haiqing in [9] used TOGAF to build the more perfect corporate level Enterprise Architecture in Jiangsu province based on SG186 Information Engineering. It obtained 298 business abilities and 211 business objects in Business Architecture; 237 data entities and 334 major data attributes in the Data Architecture. But it did not reflect the specific relationship between these data and the business data. 


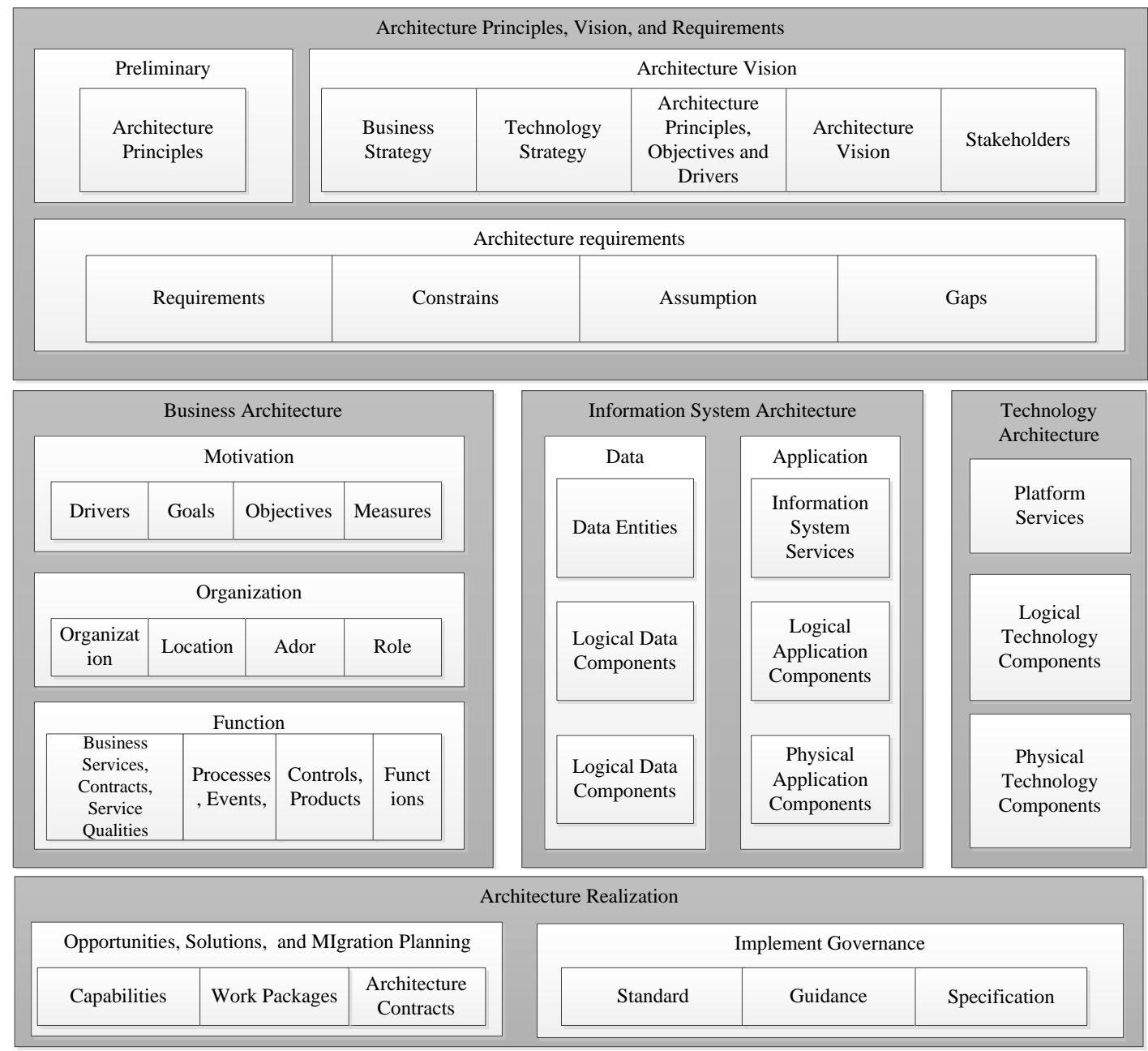

Fig. 2 TOGAF Content Framework

\section{The Shortage of the Current Enterprise Architecture Framework Method}

Main problem of the architecture in common is that most of the state-owned enterprises focus on the Technical Architecture of the enterprise, lack of Enterprise Business Architecture and Enterprise Information Architecture, especially how to build a harmonious EIA.

The current study on how to build EIA is seldom, one idea is that mapping the EBA to EIA. Mahmood Ahmad proposed an enterprise semantic derived method for enterprise BPA has given express ontology by generating BPAOnt ontology, including Business Entities, Business Processes and relationship figures between entities [10]. Then according to the BPAOnt and domain ontology, we express EIA through process ontology semantic, and the result is Information Entities, Information Flows, E-R diagrams and so on, as shown in fig.3. If the idea was applied to large state-owned enterprises, most of the above problems can be solved.

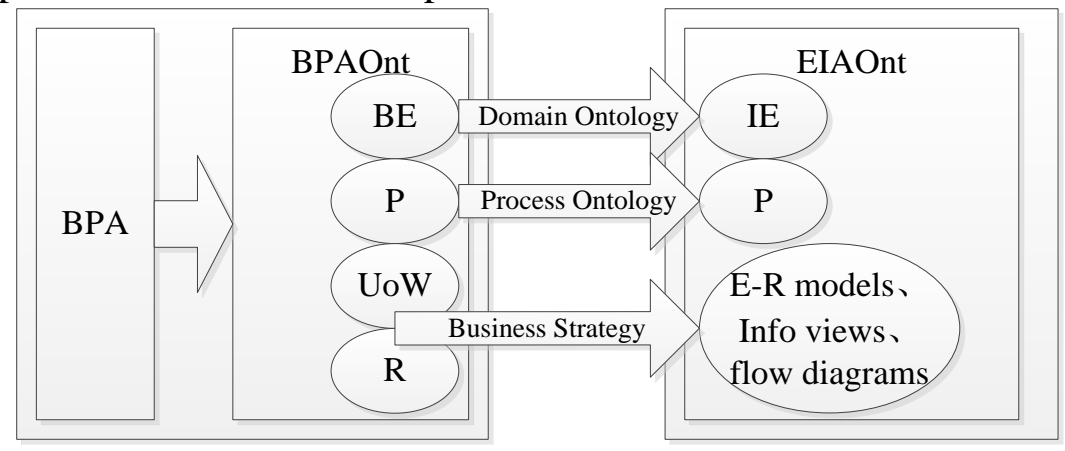

Fig. 3 The Idea of Ontology Construction EIA 


\section{Using Ontologies to Identify Information Architectural Components}

\section{The Basic Concept}

The Riva Method. The Riva Method which is proposed by Martyn Ould [11] is the organization process of extraction, modeling, analysis and design method. It uses the Process Architecture Diagram (PAD, used to organize activities in all groups described as a separate process) and the Role Activity Diagram (RAD, used to describe a single process) to discuss process. In a modeling project, we should have a PAD and a number of RADs.

BPMN. Business Process Modeling Notation (BPMN) which is a standard of process design can be unified enterprise all aspects of process design and management [8]. The biggest characteristics of BPMN method is that a flow chart can be converted to BPEL (Business Process Execution Language).

Ontology. Ontologies represent shared knowledge of and about things, the relationships between things. Tom Gruber has defined ontology as "specification of shared conceptualization". Breitman and Leite have modified this definition as "an explicit formal specification of shared conceptualization". Ontologies are popularly used to represent the knowledge of things through domain ontologies and actions through process ontologies. Ontologies are machine executable [9] and this enables them to capture complex knowledge for the requirements engineering phase of Software Engineering.

\section{The BPA Ontology (BPAOnt)}

Yousef in [1] put forward BPAOntoSOA Framework to build a semantic knowledge-base of Business Process Architecture (BPA) of an enterprise in the form of an Ontology called the BPAOnt Ontology. The BPAOnt Ontology captured the BPA elements of the enterprise using Ould's Riva methodology, and the result is Business Entities and Business Processes within the enterprise. Yousef's BPAOntoSOA framework goes on to identify the set of candidate services for a service-oriented architecture [1]. The Riva's BPA methodology is mainly concerned with Essential Business Entities (EBEs) that an organization deals with and identifies business processes along a subset of EBEs that qualify to become units of work (UoWs) [12]. Also, EBEs drive in subsequent stages the generation of more accurate business process architecture of enterprise far more reflective than the ones generated by models of organizational communications [13]. We envisage that these EBEs in association with process of generating a BPA carry information and qualify to become information entities (IEs) as part of the EIA.

The BPAOnt Ontology combines the sBPMN Ontology from the Semantic Business Process Management (SBPM) project [14], which provides an ontological representation of BPMN models of an organization's business processes, and the srBPA Ontology for the Riva Methodology. The sBPMN Ontology is essential because the starting point for the BPAOntoSOA framework is business process models for its instantiation to any case study, as depicted in Fig. 4. We use RADs to generate an enterprise or the organization's business process model and then change them into the corresponding BPMN models. For EIA, BP models drawn from the resulting Riva based BPA are more significant as these can be used for drawing more critical informational elements such as EBEs.

\section{The Sematic Approach to Derive EIA from BPA}

Fig.4 represents the EIA semantic derived simple view. This method relies on BPAOnt ontology to capture Business Process Architecture model and the information entities, equivalent to the process of ontology mapping. 


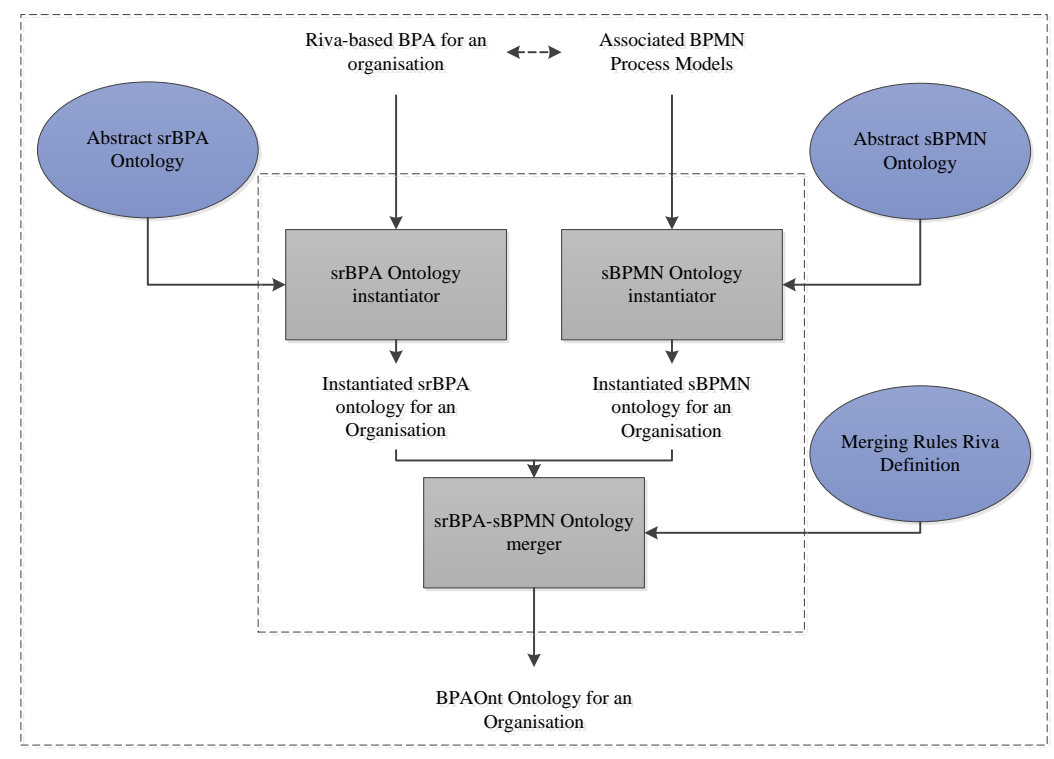

Fig.4 BPAOnt Instantiation by Yousef

\section{The Information Entities of EIA}

BPAOnt depicts all Business Entities as the basic BEs. However, some of these entities are present because an organization has chosen to function in a particular way. Thus derivation of IEs is significantly dependent upon the way BPAOnt has chosen its EBEs.

Semantic analysis of a business system can provide the knowledge of the BEs associated with Enterprise Business Process. A good approach for collecting business information is to analyze business process models in BPMN. The semantic knowledge of BEs can be an effective starting point for the purpose of identifying Information Architecture and other elements of EIA. However, a complete set of IEs is formed by searching the domain ontologies of the concerned business processes for IEs that are conceptually related to IEs in the initial set. For the case-studies which have no domain ontology yet, the knowledge or requirement engineers will need to develop the associated domain ontology in order to derive the related IEs. First identify the basic BEs, some BEs can be used as the segmentation of other BEs, and some of the work unit are also can be used as the segmentation process of other high-level activities. Basic BEs such as retail managers, investment advisors, analysts and Banks entrust member can be seen as the segmentation of bank employees. The bank employees and retail can be seen as the sub-concept of people. This means that the ontological specification of this knowledge should be carried out in such a way that concepts have "is-a" relationships are effectively identified when generating the IEs.

\section{The EIA Processes}

First EIA process use Case Strategy Processes (CSPs) [11]. Each unit of work should have its corresponding Case Strategy Processes which generate Case Processes (CP) and Case Management Process (CMP). The two processes form the initial set of the EIA process. According to the complexity of each process, CP and CMP can be broken down into tasks and activities from the initial set. For internal task of the EIA, it also exist a series of the EIA process, these processes have contact with other parts of the EIA. At present, the BPAOnt is short of the CSP, but this process is linked to the EIA of elements and business strategy. CSP analyzes the application of Case Process and it corresponds to the Unit of Work, BEs, and IEs. CSP is directly used in business strategy to identify BEs and presents related IEs.

\section{Other EIA Components}

Other elements include Entity-Relationship diagrams, traceability matrices and information flow charts. Entity-relationship diagram contains IEs, and the relationship between them has no 
classification. The IEs identified by domain ontology also follows these relationships. Several IEs may correspond to one BE of the BPA. On the contrary, many BEs may be related to one IE, thus forming a many-to-many relationship between BEs in BPA and IEs in EIA. Traceability matrices are used to assist the Information Architect for supporting information Value Chains and producing information flow diagrams. These include BE/IE traceability matrix, CP/IE matrix, IE/EIA Process matrix etc.

\section{Summary}

This paper introduced a new approach for the semantic derivation of enterprise information architecture (EIA) from the semantic representation of organization's BPA based on Yousef's BPAOntoSOA Framework and Ould's Riva BPA methodology. We have also proposed improvement to Yousef's BPAOnt Ontology by including Riva's CSP for each UoW, as our concept of a generic EIA considers CSPs to be instrumental in not only maintaining a strategic view of UoW but also a link with entities and processes. Most of the architectural artifacts of the BPA can lead to EIA components with the help of existing domain and process ontologies. When given an instance of a particular enterprise, this new approach draws assistance from ontologies of the given domain to derive the associated EIA.

We expect the EIA ontology model can be applied to large state-owned enterprises and improve some problems about information architecture construction the enterprise existed. The ontology model is not only consistent with the BPA, but also represents the general concept of the EIA.

\section{Acknowledgement}

This research was financially supported by the Research Base Construction: State-owned Assets Management Collaborative Innovation Center (19005418036).

\section{References}

[1] R.Yousef, M.Odeh, D.Coward, et al. BPAOntoSOA: A generic framework to derive software service oriented models from business process architectures[C]//Applications of Digital Information and Web Technologies, 2009. ICADIWT'09. Second International Conference on the. IEEE, 2009: $50-55$.

[2] R.Evernden, E.Evernden. Third-generation information architecture. Communications of the ACM, 2003, 46(3): 95-98.

[3] J.T.C.Teng, W.J.Kettinger. Business process redesign an information architecture: exploring the relationships. ACM SIGMIS Database, 1995, 26(1): 30-42.

[4] W.J.Kettinger, J.T.C.Teng, S.Guha. Information architectural design in business process reengineering. Journal of Information Technology, 1996, 11(1): 27-37.

[5] CH.Fang. Modeling Method Based on the Zachman Framework for the Requirement Engineering of Information System. Journal of Chongqing Jiaotong University. 2007.26(2):155-159.

[6] J.X.Wang, SH.Y.Yu. The Top-level Design of the Electronic Government Affairs:The Method System Research of FEA. E-Government Affairs. 2011.8:19-29.

[7] ZH.H.Xie, H.X.Leng. DoDAF and its Apply to U.S Army Weapon and Equipment System-of-System Architecture Development. Defence Science and Technology. 2011.4:25-31.

[8] H.L.Yu. Enterprise Architecture. Oriental Press, 2009.

[9] H.Q.Xu, M.M.Zhang. The Information Technology Model Based on Enterprise Architecture. Electric Power IT. 2011.9(2):32-35. 
[10] M.Ahmad, M.Odeh. Semantic Derivation of Enterprise Information Architecture from Business Process Architecture. ICCTA, 2012(10):79-84.

[11]M. A. Ould, Business Process Management: A Rigorous Approach. British Computer Society, UK, 2005.

[12] M.A.Ould. Preconditions for putting processes back in the hands of their actors. Information and Software Technology, 2003, 45(15): 1071-1074.

[13] M. A. Ould, "Preconditions for putting processes back in the hands of their actors," Information and Software Technology, vol. 45, no. 15, pp. 1071-1074, 12/1 2003.

[14] SUPER. Deliverable 7.2 M18: Semantic web services-based business process architecture. SUPER Project, Tech. Rep. Version 2.0, 2007, URL: http://www.ip-super.org/res/Deliverables/M18/D7.2.pdf, accessed on November 1, 2009 at 18:59. 